\title{
The Comparison of Selected Risk Management Methods for Project Management
}

\author{
Vladěna Obrová and Lenka Smolíková \\ Brno University of Technology, Faculty of Business and Management, \\ Kolejni 4, 61200 Brno, Czech Republic \\ \{obrova, smolikova\} @ fbm. vutbr.cz
}

\begin{abstract}
Project management is a set of validated and described procedures that comprehensively solve the implementation and management of defined activities that relate to a specific project. In the Czech Republic, the issue of risk management in projects often neglected and began to be more used to the ESF projects where is the risk management required. There are used most often for risk analysis 3 methods - sensitivity analysis, RIPRAN method, scoring method. The following article focuses on risk management methods that are not used in common practice immediately concern to project risk management. The benefit of this paper is the connection between methods used in project management and the methods of risk analysis. The result is an overview of the main advantages and disadvantages of these methods and the possibility of their use in different phases of the project, taking into account the time and cost effectiveness.
\end{abstract}

Keywords: project management, risk management, ETA, HRA, FMEA, comparison.

\section{$1 \quad$ Introduction}

The purpose of project management is to ensure effective management of these activities so as to bring the expected results and benefits in the shortest time. Project management is thus the application of knowledge, skills, activities, tools and techniques to project so that the project will satisfy the requirements imposed on it and achieve their goals. Risk management is also an integral part of project management, which should be incorporated into.

Risks are associated with all the activities that may occur in the individual life cycle of the project. The paper compares existing methods and their applicability and appropriateness in the management of the project, taking into account the time and cost effectiveness of each method.

The project includes already defined analytical methods that can be further used in risk management. One of these methods is the method of network analysis (CPM, PERT, or other), which is used to observe the total duration of the project and the creation of a critical path. To identify activities for the method of network analysis, there is used the method WBS (Work Breakdown Structure). This method is used for 
a detailed segmentation of each activity in the project so that it can be assigned responsibility for these activities. In further analysis of risk, it is appropriate to focus on these critical activities, which may result in a delay that would result in delay of the project as a whole. It is also suitable to use the responsibility matrix to assign and display of responsibilities between team members in projects, processes or parts thereof. There are more variations of the matrixes; the most common are RACI matrix and its extension RASCI. These 3 methods above are used as a basis for risk analysis.

Among the analyzed selected risk management methods belong ETA and FMEA. ETA method is based on event tree analysis - ETA (Event Tree Analysis). ETA is used as a causal analysis technique, which is used to evaluate the process and the possible events leading to the accident. Another method is to analyze the possible defects and their consequences - FMEA (Failure Mode and Effect Analysis). It is an analytical technique, which aims to identify potential sites of defects or faults in systems. The method FMEA is a systematic identification of all possible defects in the product or process and its implications, identifying steps to prevent, reduce or limit the causes of these defects and document the entire process.

The paper deals with risk management issues in project management. In project management, risk management is a systematic process that aims to identify and manage risk, in order to act on its appearance (eliminating, minimizing or controlling it), by implementing systems and procedures to identify, analyze, evaluate and address the risks inherent to any project. [1] [2]

Risk management is a structured approach for the identification, assessment, and prioritization of risks followed by planning of resources to minimize, monitor, and control the probability and impact of undesirable events. [3]

Risk management is an essential part of every project; no project is free from risks. At any stage of a life cycle, a project is plagued with various risks due to the complex and dynamic nature.[4]

Risk management must contribute to define the different project objectives, improve project control, increase the chances of project success, improve communication between project participants and facilitate decision-making and prioritise actions. [5] [6] [7]

Despite this fact, risk management is often left aside in project management practice, or is not given due attention. Therefore, risk management can help project managers to anticipate delays that cause projects not to be delivered on time. [8]

The project team may encounter risks throughout the whole life cycle of the project, i.e. in all of its phases.

Smith described principles and guidelines for effective risk management and emphasized the importance of active risk management for accelerating projects and improving their success rates. [9] Raz et al. performed an empirical study and reported that risk management practice is more applicable for higher-risk projects and appears to be related to project success.[10]

The paper focuses on the comparison of three methods: ETA, HRA, and FMEA; all three are methods that are commonly used for risk management in a company, but have not been incorporated into the field of project management. The first chapter describes and explains these methods, afterwards they are compared and their advantages and disadvantages are reviewed. 


\section{Theoretical Description of ETA, HRA and FMEA Methods}

\section{$2.1 \quad$ ETA}

The first selected method is ETA (Event Tree Analysis). It is a causal analysis technique that is used to evaluate the process and its events leading to a possible accident. ETA method does not take into account the causes of an undesirable event, but is assessing further development of the events, thus providing an overview of the probability of possible resulting events. The principle of this method is to observe the events, their sequence and relationships between them, which not only lead to a malfunction, but also to a failure of the system. Within the framework of the method, each activity is analyzed and its sequences are graphically displayed using the event tree model, where these activities can be further evaluated quantitatively. A logical diagram describes the logical development of the scenario, starting from the initiating event to possible serious consequences. It is an inductive, systematic approach developing the initiating event through successive, logical steps (possible sequences). The results of ETA analysis are different accident scenarios. The analysis may be performed by one analyst, but it is preferable to employ more analysts. Analysts can use the results for recommendations on reducing the likelihood and/or consequences of potential failures. The method is used for identification and analysis of the system, project and process weaknesses. The result is a set of recommendations to reduce the likelihood of an accident and to mitigate its consequences. [11]

\subsection{HRA}

Another method used in identifying risks within the company is HRA (Human resource analysis). This method is used to identify potential risks resulting from human factor that is present in any activity occurring not only in the company, but also in the project team. It is therefore appropriate to analyze the human component in project planning and its implementation to allow not only for current use of the results of the analysis, but also for their future application, thus avoiding the risks associated with human factor failure. It is a systematic evaluation of factors affecting the work of team members including technicians, maintenance engineers and other employees of the company. The aim is to identify potential human errors, their causes and consequences. HRA explores the relationships between certain key areas. The interviews focus on the following areas:

- communication and information;

- duties;

- internal environment;

- education;

- system of rewards;

- work conditions;

- company management;

- total satisfaction with the work. 
The method is usually used in conjunction with other methods that allow quantification of results. If we apply the method using event trees or fault trees, it is possible to graphically illustrate the sequence of human failure and its impact on the result of the activity, or project. The method should be employed by two analysts as a minimum that must be familiar with the interviewing technique; it is a very demanding method requiring experience on the part of the analyst in order to interpret the interviews in a proper manner.[12]

\subsection{FMEA}

Still another method is FMEA (Failure Mode and Effect Analysis). Again, it is an analysis technique that is used to identify areas where a failure or another malfunction of the system might occur. The principle of this method is based on the quantification of the frequency of failures, their severity and ease of their detection. Due to its versatility, it can be used in a number of areas, in particular in the area of risk management and quality management, or security management. The method creates a table of causes of failures and their impacts on the system, company or project. FMEA identifies simple failures that can significantly contribute to an accident, but cannot be included in an exhaustive list of failures. It is easily applicable when a process change or modification takes place, or if a new process is introduced. It can be conducted by one analyst, but should be reviewed by another one. It also includes an estimate of the worst case consequences. It is usually documented in a tabular form including recommendations for improving safety. It is a preventive method which allows for timely identification of possible failures, errors or defects that may affect the operation of the system or the resulting quality or safety. This method recognizes risks at an early stage of planning, thus reducing the level of risk, and, therefore, it is saving time and providing a possibility to invest the time into other areas. The method requires a lot of experience of the team with the analyzed system. An extended version of this method called FMECA (Failure Mode and Effect Critical Analysis) is also used. [13][14]

\section{Risk Management Process in Projects}

Risk management in a company should be implemented through the following phases: risk identification, risk analysis, risk assessment, risk treatment and risk monitoring. [15] [16]

\subsection{Risk Identification}

In this phase, hazards that may threaten the project are identified; we are trying to list and describe these hazards as accurately as possible. It is unfeasible to compile a complete list of all risks threatening the project; it is necessary to identify significant risks that can adversely affect the success of the project. At this stage it is advisable to use one of the creativity techniques, such as brainstorming or the Crawford Slip method. 


\subsection{Risk Analysis}

This phase is based on the compiled list of risks, and includes an effort to evaluate the risks: the likelihood of occurrence of a certain hazard, and to estimate the adverse impact on the project (incurred financial damages). Risk analysis can be quantitative (the value of probability and the value of loss using a straight numeric value is determined), or qualitative (used to determine the probability and the loss of verbal value). Finally, the risk value is calculated, again using quantitative and qualitative approach.

\subsection{Risk Assessment}

The purpose of this step is to make a decision which risks should be treated, which are to be omitted, or, conversely, which are unacceptable. It can be based on the Pareto principle, i.e. the $80 / 20$ rule. Thus, $20 \%$ of major risks should be treated very carefully; even using the majority of funds for risk treatment, and the remaining funds should be kept as a reserve.

\subsection{Risk Treatment}

If the risk value is determined and we have decided to treat the risk in a way, we should consider how we will respond to the risk. The aim of this phase is to reduce the total value of all risks to such a level so that the project is feasible with high probability. A higher value of risk should be treated with appropriate measures reducing the risk value. The following includes typical measures that are most commonly used:

- provide insurance against the adverse event;

- eliminate the risk by finding an alternate solution that does not contain a hazardous event;

- create a reserve;

- create a backup Plan B.

\subsection{Risk Monitoring}

Once a risk analysis has been completed, and we continue in implementing the project, it is necessary to constantly monitor all risks. Risk monitoring is the most frequent issue on the agenda of project meetings.

The phases of risk identification, risk analysis, risk assessment and risk treatment are carried out within the pre-project (or planning) stage, while risk monitoring is done within the project stage (which is also referred to as the implementation phase); the post-project stage includes evaluation of the whole risk management process in the project.

\section{Comparison of Methods}

The following tables show an overview of the main advantages and disadvantages of using the methods in project management, as well as a comparison of their timeconsuming nature and costs, and last but not least, the phase of the project in which it is appropriate to use the methods, and types of projects for which they are best suited. 
Table 1. Advantages and Disadvantages

\begin{tabular}{|c|c|c|}
\hline Method & Advantages & Disadvantages \\
\hline ETA & $\begin{array}{l}\text { 1.The ability to take into account } \\
\text { the time-sequence, dependency or } \\
\text { domino effect factors; } \\
\text { 2. Well-arranged overview of con- } \\
\text { secutive actions; } \\
\text { 3.Possibility to continue working } \\
\text { and quantify the results of the } \\
\text { analysis. }\end{array}$ & $\begin{array}{l}\text { 1.An event tree must be built for } \\
\text { each event.; } \\
\text { 2.Conditional probabilities de- } \\
\text { pendent on previous events in } \\
\text { the path } \rightarrow \text { omission of the de- } \\
\text { pendence or its incorrect inter- } \\
\text { pretation. }\end{array}$ \\
\hline FMEA & $\begin{array}{l}\text { 1.Objective evaluation of the design, } \\
\text { including functional requirements } \\
\text { and alternative suggestions; } \\
\text { 2.Increased probability that a fail- } \\
\text { ure and its consequences, if any, } \\
\text { will be identified in the early } \\
\text { stage of the project design or its } \\
\text { development; } \\
\text { 3.Improvement in the quality of } \\
\text { manufactured products, services } \\
\text { or processes } \\
\text { 4.Development of a list of potential } \\
\text { failures (defects) that are listed } \\
\text { according to the value of their } \\
\text { impact on the project; } \\
\text { 5.Identification of additional in- } \\
\text { formation to support the devel- } \\
\text { opment, design and planning; } \\
\text { 6.Significant psychological effect, } \\
\text { strengthening the involvement of } \\
\text { employees; } \\
\text { 7.Improving communication be- } \\
\text { tween the employees and different } \\
\text { departments of the organization. }\end{array}$ & $\begin{array}{l}\text { 1.Complexity; } \\
\text { 2.Toilsomeness of the task of } \\
\text { mapping large amounts of in- } \\
\text { formation about the system or } \\
\text { project, such as technology, } \\
\text { function, operation, range, etc.; } \\
\text { 3.Human error. }\end{array}$ \\
\hline HRA & $\begin{array}{l}\text { 1.Elimination of human errors prior } \\
\text { to the beginning of the project or } \\
\text { during its implementation } \\
\text { 2. An overview of the skills and } \\
\text { knowledge of team members dur- } \\
\text { ing the project or when building } \\
\text { the team; } \\
\text { 3.Measures against discontent of } \\
\text { team members and their errone- } \\
\text { ous performance caused by a lack } \\
\text { of communication between the } \\
\text { management and other industries. }\end{array}$ & $\begin{array}{l}\text { 1. Time required for conducting } \\
\text { the interviews with all team } \\
\text { members } \\
\text { 2.In the case of a bad choice of } \\
\text { the analyst, a human error } \\
\text { may occur even after complet- } \\
\text { ing the analysis; } \\
\text { 3. Reluctance of employees to } \\
\text { cooperate during the inter- } \\
\text { views, or intentionally biased } \\
\text { information provided about } \\
\text { themselves, leading to misin- } \\
\text { terpretation of the outcome of } \\
\text { the interview. }\end{array}$ \\
\hline
\end{tabular}


Table 2. Time and Costs

\begin{tabular}{|c|c|c|}
\hline Method & Time & Costs \\
\hline ETA & $\begin{array}{l}\text { 1. If the necessary software is pur- } \\
\text { chased, the method requires min- } \\
\text { imum efforts; } \\
\text { 2. If a detailed analysis is made, it is } \\
\text { very challenging to incorporate } \\
\text { each event into the tree of subse- } \\
\text { quent events. }\end{array}$ & $\begin{array}{l}\text { 1. The cost of software purchase } \\
\text { 2. Training an operator of the } \\
\text { program, and engaging an em- } \\
\text { ployee or employees who will } \\
\text { develop the analysis. }\end{array}$ \\
\hline FMEA & $\begin{array}{l}\text { 1. Highly time-consuming in the } \\
\text { case of systems or projects that } \\
\text { are composed of many compo- } \\
\text { nents and activities, and include } \\
\text { numerous functions; } \\
\text { 2. The first application of the me- } \\
\text { thod in the company or in the } \\
\text { project team to a complex system } \\
\text { is also time-consuming. }\end{array}$ & $\begin{array}{l}\text { 1. The costs of FMEA analysis } \\
\text { are minimal and are counterba- } \\
\text { lanced by the certainty that eve- } \\
\text { rything has been done for a } \\
\text { smooth implementation of prod- } \\
\text { uct, process, system, or project; } \\
\text { 2. In the case of the first applica- } \\
\text { tion, increased costs due to } \\
\text { staff workload. }\end{array}$ \\
\hline HRA & $\begin{array}{l}\text { 1. Dependent on the length of inter- } \\
\text { views in direct proportion to the } \\
\text { number of analysts performing } \\
\text { the analysis. }\end{array}$ & $\begin{array}{l}\text { 1. The cost of own employee train- } \\
\text { ing who will implement the me- } \\
\text { thod as an analyst; } \\
\text { 2. Hiring an external company to } \\
\text { perform the analysis; } \\
\text { 3. Incorporation of the interviews } \\
\text { into the working hours, and the } \\
\text { necessity to reimburse the em- } \\
\text { ployees or team members for } \\
\text { this time as hours worked. }\end{array}$ \\
\hline
\end{tabular}

Table 3. Project Phase and Project Type

\begin{tabular}{|c|l|l|}
\hline Method & Project Phase & Project Type \\
\hline ETA & $\begin{array}{l}\text { 1. Pre-project phase: risk identifica- } \\
\text { tion, risk analysis. }\end{array}$ & $\begin{array}{l}\text { 1. All types of projects: introduc- } \\
\text { tion of a new product, service, } \\
\text { innovation, software develop- } \\
\text { ment. }\end{array}$ \\
\hline FMEA & $\begin{array}{l}\text { 1. Pre-project phase: risk identifica- } \\
\text { tion, risk analysis. }\end{array}$ & $\begin{array}{l}\text { 1. Industrial area: introduction of } \\
\text { new products and systems, in- } \\
\text { novation. }\end{array}$ \\
\hline HRA & $\begin{array}{l}\text { 1. Pre-project phase: risk identifica- } \\
\text { tion. }\end{array}$ & 1. Without any limitations. \\
\hline
\end{tabular}

The main disadvantage of the above methods is that they only deal with risk identification, and not with risk analysis and identification of countermeasures that should eliminate the risk, or reduce its likelihood or impact on the project. 


\section{Conclusion}

The paper describes the risk management methods that are not commonly used in project management practice. The risk management process in the project is also described, including the various stages of the project. The contribution of the paper is the comparison of ETA, FMEA and HRA methods, and presentation of their use in the context of project management. Advantages and disadvantages of each method are outlined, as well as the time and costs associated with it. The paper further shows the phases and types of projects in which it is suitable to use the methods. It is definitely advisable to use the above methods in project management, but their great disadvantage must not be left aside, i.e. the fact that they do not propose any countermeasures against the risks that are identified. In their application, it is therefore appropriate to focus on the choice of countermeasures, or risk management strategies in compliance with the whole project in its various stages.

\section{References}

1. Conroy, G., Soltan, H.: ConSERV, a project specific risk management concept. International Journal of Project Management 16, 353-366 (1998)

2. Raz, T., Michael, E.: Use and benefits of tools for project risk management. International Journal of Project Management 19, 9-17 (2001)

3. Smith, P.G., Merritt, G.M.: Proactive Risk Management: Controlling Uncertainty in Product Development. Productivity Press, New York (2002)

4. Zhao, X., Chen, Q.: Reconsidering Baron and Kenny: myths and truths about mediation analysis. Journal of Consumer Research 37, 197-206 (2010)

5. AFNOR: Norma FD X 50-117 Management des Risques d'un Project (2003)

6. Courtot, H.: La gestion des risiques dans les projects. Edition Economica, Paris (1998)

7. Courtot, H.: Quelques renseignements liés à la mise en oeuvre d'une démarche de gestion des risques dans les projets. La Cible-A.F.I.T.E.P. 74 (1998)

8. Grant, K.P., Cashman, W.M., Christensen, D.S.: Delivering projects on time. Research \& Technology Management 49, 52-58 (2006)

9. Smith, P.: Managing risk as product development schedules shrink. Research Technology Management 42, 25-32 (1999)

10. Raz, T., Shenhar, A.J., Dvir, D.: Risk management, project success, and technological uncertainty. R\&D Management 32, 101-109 (2002)

11. Korecký, M., Trkovský, V.: Management rizik projektů. Grada Publishing, Praha (2011)

12. Tichý, M.: Ovládání rizika: analýza a management. C.H. Beck, Praha (2006)

13. Nenadal, K.: Moderní systémy řízení jakosti. Quality Management. Management Press, Praha (1998)

14. Zeman, M.: Diplomová práce. Univerzita Tomáše Bati ve Zlíně, Fakulta technologická, Ústav výrobního inženýrství, Zlín (2010)

15. Doležal, J., Mácha, P., Lacko, B.A.: Kolektiv: Projektový management podle IPMA. Grada Publishing, Praha (2012)

16. Smejkal, V., Rais, K.: Rízení rizik ve firmách a jiných organizacích. Grada, Praha (2009) 